\title{
FMR1 Gene
}

National Cancer Institute

\section{Source}

National Cancer Institute. FMR1 Gene. NCI Thesaurus. Code C75421.

This gene may be involved in the regulation of mRNA trafficking. 